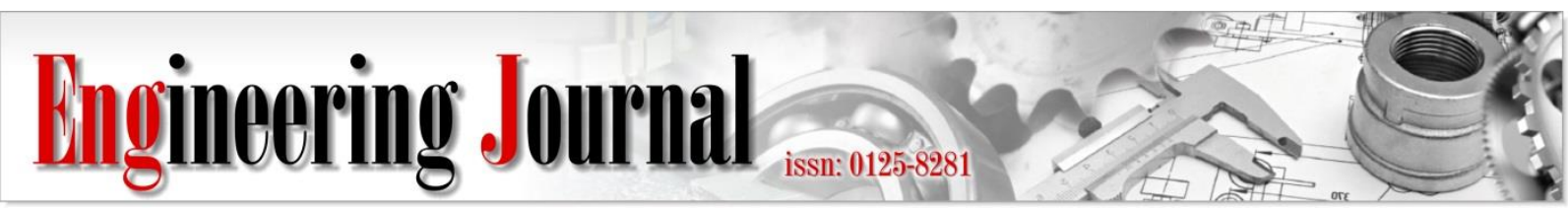

Article

\title{
A Field Survey of Thermal Comfort in Air-conditioned Space in Songkhla's Hot Humid Climate
}

\author{
Ashmin Aryal $^{1}$, Pipat Chaiwiwatworakul ${ }^{1, *}$, Surapong Chirarattananon ${ }^{1}$, \\ and Satinee Wattanakit ${ }^{2}$ \\ 1 The Joint Graduate School of Energy and Environment, CHE Center for Energy Technology and \\ Environment, King Mongkut's University of Technology Thonburi, 126 Pracha-Uthit Road, Bangmod, \\ Tungkru, Bangkok 10140, Thailand \\ 2 Faculty of Architecture, Rajamangala University of Technology Srivijaya, 1 Ratchadamnoennok Road, \\ Boyang Sub-district, Muang District, Songkhla 90000, Thailand \\ E-mail: *pipatc@gmail.com (Corresponding author)
}

\begin{abstract}
This paper reports the study results from a field comfort survey of people in hot humid climate of Songkhla, a province in southern Thailand (latitude $7.20^{\circ} \mathrm{N}$ and longitude $100.59^{\circ} \mathrm{E}$ ). Thermal sensation, thermal acceptability, and thermal preference were assessed from the observations of three hundred subjects in air-conditioned spaces in buildings. The analysis showed that the operative temperature for the thermal neutrality $(\mathrm{TVS}=0)$ was $26.3^{\circ} \mathrm{C}$, and the acceptable temperature range (TVS $\left.= \pm 0.5\right)$ was $25.6-27.1^{\circ} \mathrm{C}$. The air movement played a key role to improve the people thermal sensation and preference, but the relative humidity performed less impact. In our study case, the PMV model could not well applied to Songkhla's people as it predicted the neutral temperature one and a half degree colder than the actual, and underestimated the hyper-sensitivity of the thermal sensation to the temperature.
\end{abstract}

Keywords: Thermal comfort, predictive mean vote, thermal sensation vote, thermal acceptability, thermal preference, hot and humid climate.

ENGINEERING JOURNAL Volume 25 Issue 2

Received 7 February 2020

Accepted 25 November 2020

Published 25 February 2021

Online at https://engj.org/

DOI:10.4186/ej.2021.25.2.235 


\section{Introduction}

Thermal comfort is the condition of mind that expresses satisfaction with the thermal environment and is assessed by subjective evaluation. Physically, thermal comfort is influenced by the four environmental-related factors i.e. air temperature, air humidity, air velocity, and mean radiant temperature, and the two personal-related factors i.e. metabolic rate, and clothing insulation $[1,2]$.

According to ANSI/ASHRAE standard 55 and ISO 7730 , thermal comfort of a large group of people could be rated in terms of Predicted Mean Vote (PMV) and Predicted Percentage of Dissatisfied (PPD) indices. The PMV value is calculated using the Fanger's human heat balance model with the above six factors [3]. It should be noted that the Fanger's model was developed empirically based on the experimental data from subjects in the midlatitude regions tested in a well-controlled environmental chamber.

Although internationally standardized; thermal comfort has been well perceived to be adaptive and psychological, and could not be exactly specified at a condition of temperature or relative humidity [4]. Several publicized research studies have indicated that the state of comfort relied on a wide range of non-quantifiable factors such as mental states habits, education, etc. of people [5-8]. Among these psychological factors, the one most studied was acclimatization of people to a particular climate. Past studies confirmed that preference of people in different locations varied accordingly with their longterm experience to prevailing local climate. Field comfort surveys in tropical climate such as [10-12] in Brazil, [13] in China, [14] in India, [15-17] in Malaysia have shown that the people tolerated to higher temperature and humidity, and could achieve thermal comfort at different conditions as compared with people in colder or mild climate regions.

In Thailand and Singapore, thermal comfort has been studied including both the air-conditioned and naturally ventilated buildings. Some of which focused on the thermal comfort in air-conditioned room were those of Busch in 1990 [5], Hirunlabh et al. in 2005 [6], and De Dear in 1991 [7]. Form his field survey, Busch reported Thai's people in Bangkok achieved their thermal neutrality at operative temperature of $24.5^{\circ} \mathrm{C}$. However, the study of Hirunlabh et al. that carried out the survey in three provinces of Chiangmai, Bangkok, and Prachuap khiri khan presented Thai people felt comfort at the room air temperature between $25-26^{\circ} \mathrm{C}$, higher than that reported by Busch. Hirunlabh et al. also found that Thai's people accustomed to living long time in airconditioned space as in Bangkok preferred neutral comfort air temperature $1^{\circ} \mathrm{C}$ lower than those did not use air-conditioner at home. A comfort study in hot humid Singapore presented the comfort temperature was as low as $23.5^{\circ} \mathrm{C}$ similar to that of people in moderate climate [8]. The reason was due to that the subject acclimated with the standard temperature setting at $23.5^{\circ} \mathrm{C}$.
In this study, a field survey would be conducted in Songkhla province to investigate the thermal environment of air-conditioned spaces in buildings and the responses of the occupants on thermal comfort in terms of thermal sensation, thermal acceptability, and thermal preference. The measured data were evaluated against the comfort standard prescriptions and the results from past comfort studies. The results from this study could complement with the existed data that enhanced the understanding on the thermal comfort of people in hot humid climate.

\section{Location and Climate}

Songkhla is a province located in the lower-southern Thailand, at latitude $7.20^{\circ} \mathrm{N}$ and longitude $100.59^{\circ} \mathrm{E}$. The province experiences with tropical monsoon, intense solar radiation, and long raining period. Figure 1 illustrates temperature $(T)$ and relative humidity $(R H)$ of the ambient air in Songkhla (maximum, minimum, and average). The temperature ranged from $22.4^{\circ} \mathrm{C}$ to $38.6^{\circ} \mathrm{C}$ with a mean value of $28.3^{\circ} \mathrm{C}$. The relative humidity ranged from $37 \%$ to $98 \%$.

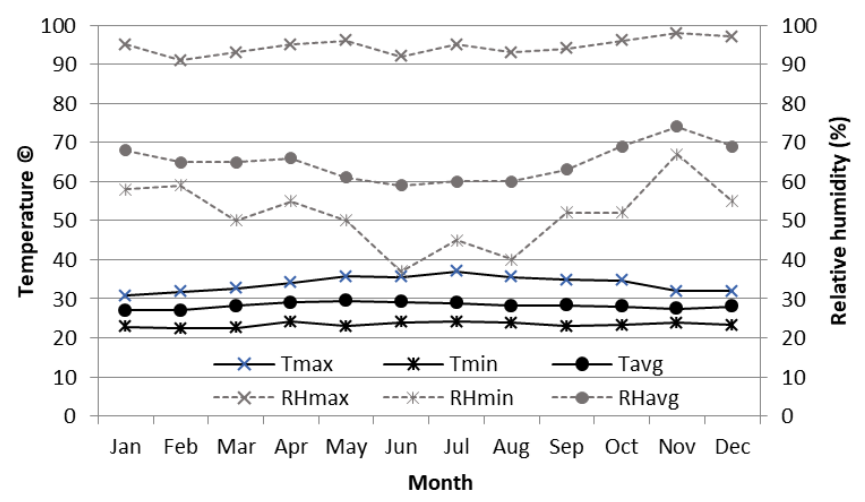

Fig. 1. Ambient condition in Songkhla.

The figure indicates that Songkhla's climate was hot and humid with small variations across a year. According to the climate condition, air-conditioning by cooling has been increasingly used to provide thermal comfort in commercial buildings.

\section{Thermal Comfort Assessment}

A field survey was conducted to assess thermal comfort from a group of Songkhla's people in airconditioned buildings (offices and classrooms) in Rajamangala University of Technology Srivijaya. All rooms were conditioned by using split-type airconditioners operated during regular office hours 8:0016:30 in working days (Monday-Friday).

The instruments in this survey were a comfort questionnaire and portable meters for measuring indoor thermal environments. In order to comply with the recommendations in ANSI/ASHRAE standard 55, the data were collected from only subjects who stayed at 
their workstations, and finished their meal longer than 60 minutes. The data collection from individuals took about 15 minutes for explaining the survey objectives and questionnaire details, and filling his/her responses in the questionnaire form.

\subsection{Questionnaire}

Comfort questionnaire was developed consisting of two sections. Section I was used compiled the subject's information i.e. name, surname, gender, age, clothing garment inventory, and behavior of air-conditioner use at home. Section II contained a series of questions to assess thermal sensation experienced by individual subject during the interview.

As shown in Table 1, the thermal comfort sensation was to be appraised by the ASHRAE seven-point scale where scale " 0 " expressed the neutrality of which subjects felt neither cool nor warm. The positive scale i.e. $+1,+2$, and +3 gave rating of the subject's sensation in warm side from "slightly warm" to "hot" while the negative scale i.e. $-1,-2$, and -3 rated the sensation in cold side.

Table 1. Rating scales for thermal sensation and acceptability.

\begin{tabular}{c|l|l|l|l}
\hline \multirow{2}{*}{$\begin{array}{c}\text { Numeric } \\
\text { scale }\end{array}$} & \multirow{2}{*}{$\begin{array}{c}\text { ASHRAE } \\
\text { sensation } \\
\text { scale }\end{array}$} & $\begin{array}{c}\text { Tempera- } \\
\text { ture }\end{array}$ & $\begin{array}{c}\text { Air } \\
\text { movement }\end{array}$ & Humidity \\
\cline { 4 - 5 } & hot & & too high & too high \\
\hline+3 & warm & & high & High \\
\hline+2 & slightly warm & truly accept & slightly high & slightly high \\
\hline+1 & neutral & Accept & neutral & neutral \\
\hline 0 & slightly cool & not accept & slightly low & slightly low \\
\hline-1 & cool & & low & Low \\
\hline-2 & cold & & too low & too low \\
\hline-3 & & &
\end{tabular}

Thermal acceptability was evaluated in three aspects of temperature, air movement, and humidity at their workstation. The subject's acceptability of the temperature was expressed by using a three-point rating scale as "truly accept", "accept", and "not accept". For the air movement and humidity, a seven-point scale was used to rate the feeling or mind from levels of "too low" through "neutral" to "too high".

Questions were also prepared for asking about thermal preference. Table 2 presents the thermal preference rating scales.

Table 2. Thermal preference rating scales.

\begin{tabular}{c|l|l|l}
\hline \multirow{2}{*}{$\begin{array}{c}\text { Numeric } \\
\text { scale }\end{array}$} & \multicolumn{3}{|c}{ Thermal preference } \\
\cline { 2 - 4 }+1 & Temperature & Air movement & \multicolumn{1}{c}{ Humidity } \\
\hline 0 & no change & no change & no change \\
\hline-1 & prefer cooler & lower air velocity & Dryer \\
\hline
\end{tabular}

The temperature preference was assessed in which the subjects preferred the room air to be "cooler" or "no change" or "warmer" referred to their prevailing condition at the time of interview. The air movement preference was assessed in a similar way which the subjects would justify for "increasing" or "decreasing" the room air velocity to improve their comfort preference. No change of the air velocity was also alternative choice. For the humidity preference, the subjects were asked for "increasing" or "decreasing" or "no change" of the room air humidity level.

\subsection{Indoor Thermal Measurement}

The thermal conditions surrounding the subjects were measured by portable meters. The measurements included dry-bulb temperature $\left(t_{a}\right)$ and relative humidity $(R H)$ of the room air, globe temperature $\left(t_{g}\right)$, and air velocity $\left(V_{a}\right)$.

According to the specifications, the meters could measure the temperature within a range of $(-20)-70^{\circ} \mathrm{C}$ and the relative humidity within a range of $0-100 \%$. The resolution was $0.1{ }^{\circ} \mathrm{C}$ for temperature and $0.1 \%$ for relative humidity. The measurement accuracies were $\pm 0.3^{\circ} \mathrm{C}$ for the temperature, $\pm 3 \%$ for both relative humidity and air velocity, and $\pm 0.2{ }^{\circ} \mathrm{C}$ for the globe temperature. These measured data were used to evaluate together with the thermal responses obtained from the questionnaires.

\section{Survey Results}

Statistical analysis was carried out to characterize the subjects and to evaluate their responses to airconditioned environment based on the comfort scales in Table 1 and 2 .

\subsection{Surveyed Buildings}

The surveyed buildings were the air-conditioned buildings in Faculty of Architecture in the Rajamangala University of Technology Srivijaya. All of them were operated for 10-15 years since the construction. The building walls were a brick layer with mortar plastering on both sides. The exterior wall surfaces were painted white. Windows were shaded by overhangs to prevent entering of solar radiation. Internal blind or curtains were typically equipped with the windows. Several surveyed rooms had one exposed wall side while others were interior walls connected to adjacent rooms and corridor.

\subsection{Surveyed Subjects}

A total of 300 subjects participated in this survey. The subject data extracted from the questionnaires are summarized in Table 3.

The age of the subjects was from younger than 20 years to older than 40 years. However, up to $75 \%$ percent was the bachelor degree students who were younger than 25 years old. Older than 40 years were the faculty members and supporting staffs. The proportion between male and female of the group were 50:50. Only 30\% of the total subjects slept in air-conditioned bedroom at 
home; indicating the majority of the group still acclimatized with natural environment than indoor climate-control space.

Table 3. Summary of the subjects' data from the survey.

\begin{tabular}{l|l|r|r|r}
\hline \multicolumn{2}{c|}{ Information } & Male & Female & Total \\
\hline Age (year) & $<20$ & 35 & 44 & 79 \\
\cline { 2 - 5 } & $20-25$ & 79 & 68 & 147 \\
\cline { 2 - 5 } & $25-30$ & 1 & 9 & 10 \\
\cline { 2 - 5 } & $30-35$ & 10 & 10 & 20 \\
\cline { 2 - 5 } & $35-40$ & 20 & 7 & 13 \\
\cline { 2 - 5 } & $>40$ & $\mathbf{1 5 1}$ & $\mathbf{1 4 9}$ & $\mathbf{3 0 0}$ \\
\cline { 2 - 5 } & Total & 0.51 & 0.51 & 0.51 \\
\hline \multirow{3}{*}{$\begin{array}{l}\text { Clothing insulation } \\
\text { (clo) }\end{array}$} & Mean & & & \\
\cline { 2 - 5 } & Standard & 0.09 & 0.13 & 0.11 \\
\cline { 2 - 5 } & deviation & 0.25 & 0.32 & 0.25 \\
\cline { 2 - 5 } & Minimum & 0.93 & 0.93 \\
\cline { 2 - 5 } & Maximum & 0.89 & & \\
\hline
\end{tabular}

\subsection{Clothing Insulation}

Inventory of the subject's clothing garments was compiled and employed to calculate the clothing insulation level based on the garment values published in ANSI/ASHRAE 55. The results are given in Table 3.

Mean value of the clothing insulation was 0.51 clo for males. The standard deviation was petty small at 0.09 , as most of the subjects who were the students wore their uniform during interview. For females, the clo value was 0.51 clo, as well. The standard deviation was 0.13 , a bit higher due to varieties of clothing garments. This clothing insulation level was quite comparable to the reference clothing insulation of 0.50 for summer season prescribed in ANSI/ASHRAE 55.

\subsection{Indoor Condition and Comfort Indices}

Table 4 summarizes the measurements of the environmental variables. The room air temperature varied between $23.9^{\circ} \mathrm{C}$ and $28.8^{\circ} \mathrm{C}$ with a mean of $26.4^{\circ} \mathrm{C}$. Compared with the design indoor condition prescribed in Thai's standard for air-conditioning and ventilation system: EIT standard 3003-50 [18], the measured indoor air temperature was almost one and a half degree higher than the recommended range of the design temperature at $24.0-25.0^{\circ} \mathrm{C}$.

Table 4. Summary of the indoor condition and comfort level.

\begin{tabular}{l|r|r|r|r}
\hline Statistical parameter & Mean & S.D. & \multicolumn{1}{c|}{ Max. } & \multicolumn{1}{c}{ Min. } \\
\hline Air temperature $\left({ }^{\circ} \mathrm{C}\right)$ & 26.35 & 0.96 & 28.8 & 23.9 \\
\hline Air relative humidity $(\%)$ & 57.19 & 5.62 & 71.0 & 41.1 \\
\hline Air velocity $\left({ }^{\circ} \mathrm{C}\right)$ & 0.1 & 0.09 & 0.75 & 0.0 \\
\hline Mean radiant temperature $\left({ }^{\circ} \mathrm{C}\right)$ & 26.34 & 0.98 & 28.7 & 24.4 \\
\hline Operative temperature $\left({ }^{\circ} \mathrm{C}\right)$ & 26.35 & 0.95 & 28.75 & 24.16 \\
\hline Dew point temperature $\left({ }^{\circ} \mathrm{C}\right)$ & 17.20 & 2.09 & 21.70 & 13.70 \\
\hline PMV & 0.55 & 0.35 & 1.33 & -0.32 \\
\hline PPD & 13.98 & 8.59 & 42.22 & 5.0 \\
\hline
\end{tabular}

Relative humidity of the room air varied between $41.1 \%$ and $71.0 \%$ with a mean of $57.2 \%$. The value seemed a bit high, but still within the recommended range prescribed in the Thai's air-conditioning standard. It should be noted that air-conditioning in buildings in Thailand especially those used split-type air-conditioner would control only the room air temperature, and neglect the relative humidity.

The subject surrounding air movement was measured during the interview. The average velocity was about $0.1 \mathrm{~m} / \mathrm{s}$. In several cases, the measured values were found to be lower than the standard air velocity for the occupied zone $(0.15-0.25 \mathrm{~m} / \mathrm{s})$. It was observed that the air registers were adjusted in order that the cooled air could distribute uniformly and avoid local over cooling to the subjects.

Mean radiant temperature $\left(t_{m r}\right)$ is an important influencing factor on human comfort. It could be defined as the average temperature of the surfaces that surrounded a particular point, with which it would exchange thermal radiation. In this study, the mean radiant temperature was derived from the measured black globe temperature according to ISO 7726 [19].

From the survey, the mean value of the radiant temperature was at $26.34^{\circ} \mathrm{C}$ with the standard deviation $0.98^{\circ} \mathrm{C}$. As shown in Table 4 , the radiant temperature was quite comparable in value to the room air temperature, except the minimum case in which the radiant temperature was $0.5^{\circ} \mathrm{C}$ above the room air temperature. The low radiant temperature value would result from the small proportion of the exterior wall to the total room wall area, and the good sun shading for windows. Circulation of the cooled air within the room would help reducing the mean radiant temperature.

Operative temperature $\left(t_{0}\right)$ was next calculated by using the mean radiant temperature. The temperature is defined as the average of the mean radiant and room air temperatures weighted by their respective heat transfer coefficients. This temperature has traditionally been used to relate to thermal comfort responses. In Table 4, the average operative temperature was $26.4^{\circ} \mathrm{C}$. Figure 2 shows a plot of the operative temperature against the room air temperature. From our survey, these two temperatures were quite closed in values.

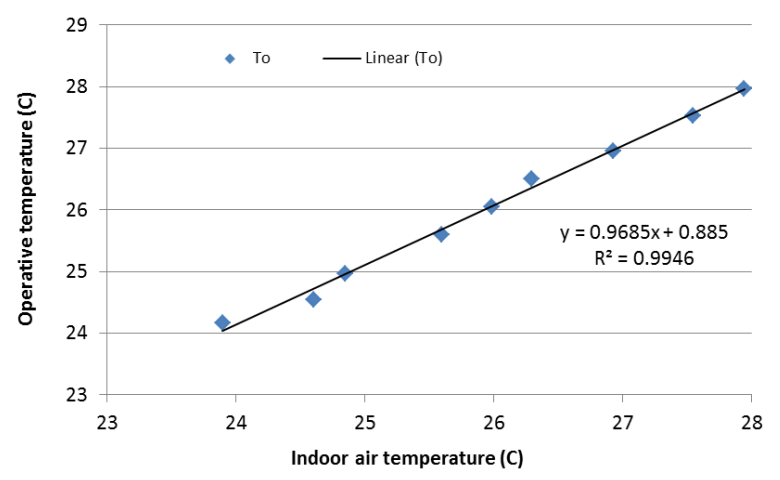

Fig. 2. The surveyed operative and room air temperatures.

According to ANSI/ASHRAE standard 55, the $\mathrm{PMV} / \mathrm{PPD}$ indices are calculated to rate the thermal 
comfort for a large group of people. As this survey conducted with working staffs in offices and students in classrooms, the metabolic rate of 1.2 met or $69.8 \mathrm{~W} / \mathrm{m}^{2}$ was reasonably assumed in the calculation. In Table 4, the calculated predicted mean vote (PMV) values were averaged at 0.55 with standard deviation 0.35 sensation scale unit; indicating that most subjects felt between "marginally above neutral" and "slightly warm". This PMV value was correspondent with the predicted percentage of dissatisfied (PPD) value of $13.98 \%$. According to the PPD model, the PPD value was minimum at $5 \%$ at the neutral comfort condition (PMV=0).

\subsection{Thermal Sensation Votes}

The subjects were assessed for their actual thermal sensation, thermal acceptability and thermal preference.

In Table 5, the individual votes (TSV) made on the ASHRAE seven-point scale covered the whole range of the sensation scale from "-3: cold" to " +3 : hot". The mean TSV was at -0.11 ; indicating marginally cooler than the neutral. The TSV standard deviation was calculated at 1.16 scale units; implying that about $70 \%$ of the subjects was in between "slightly cool" and "slightly warm". Compared to the PMV, the TSV possessed a larger distribution, as it was obtained from the actual votes by the subjects, not a mathematic relationship. It should be remarked that no subjects experienced to the direct solar radiation during the interview.

Table 5. Statistical summary of the thermal comfort scores given by the local subjects.

\begin{tabular}{|c|c|c|c|c|}
\hline Statistical parameter & Mean & S.D. & Max & Min \\
\hline Thermal sensation vote (TSV) & -0.11 & 1.16 & 3 & -3 \\
\hline \multicolumn{5}{|c|}{ Acceptability score } \\
\hline Air temp. & 0.63 & 0.57 & 1 & -1 \\
\hline Air movement & -0.57 & 0.98 & 2 & -3 \\
\hline Relative humidity & -0.1 & 0.76 & 2 & -2 \\
\hline \multicolumn{5}{|c|}{ Preference score } \\
\hline Air temp. & -0.19 & 0.61 & 1 & -1 \\
\hline Air movement & 0.41 & 0.54 & 1 & -1 \\
\hline Relative humidity & 0.16 & 0.53 & 1 & -1 \\
\hline
\end{tabular}

Table 6. The distribution of thermal sensation votes (TSV) of the subjects.

\begin{tabular}{|c|c|c|c|c|c|c|c|c|c|c|}
\hline \multirow{2}{*}{$\begin{array}{c}\text { Opera } \\
\text { tive } \\
\text { temp }\end{array}$} & \multicolumn{7}{|c|}{$\begin{array}{c}\text { Number of responses on } \\
\text { ASHRAE scale }\end{array}$} & \multirow{2}{*}{$\begin{array}{c}\text { Cumul } \\
\text { ative } \\
\text { respon } \\
\text { ses }\end{array}$} & \multirow{2}{*}{ Accept } & \multirow{2}{*}{$\begin{array}{c}\text { Neu- } \\
\text { tral }\end{array}$} \\
\hline & -3 & -2 & -1 & 0 & +1 & +2 & +3 & & & \\
\hline 24.16 & & 1 & 1 & & & & & 0.7 & 50.0 & 0.0 \\
\hline 24.55 & & 4 & 8 & 8 & & & & 7.3 & 80.0 & 40.0 \\
\hline 24.97 & & 5 & 6 & 8 & & & & 13.7 & 73.7 & 42.1 \\
\hline 25.60 & & 6 & 9 & 13 & 5 & 2 & & 25.3 & 77.1 & 37.1 \\
\hline 26.05 & 2 & 8 & 20 & 21 & 7 & & & 44.7 & 82.8 & 36.2 \\
\hline 26.51 & & 10 & 22 & 39 & 1 & 2 & & 69.3 & 83.8 & 52.7 \\
\hline 26.95 & & 3 & 9 & 13 & 14 & 4 & & 83.7 & 83.7 & 30.2 \\
\hline 27.52 & & 1 & 1 & 3 & 10 & 3 & 4 & 91.0 & 63.6 & 13.6 \\
\hline 27.97 & & & 1 & 2 & 9 & 9 & 1 & 98.3 & 54.5 & 9.1 \\
\hline 28.49 & & & & 0 & 2 & 3 & & 100.0 & 40.0 & 0.0 \\
\hline Total & 2 & 38 & 77 & 107 & 48 & 23 & 5 & 300 & & \\
\hline$\%$ & 0.7 & 12.7 & 25.7 & 35.7 & 16.0 & 7.7 & 1.7 & 100.0 & 77.3 & 35.7 \\
\hline
\end{tabular}

To further the analysis, the whole votes were sorted into ten half-degree bins of the operative temperature i.e. $23.75-24.25,24.25-24.75,24.75-25.25,25.25-25.75,25.75-$ 26.25, 26.25-26.75, 26.75-27.25, 27.25-27.75, 27.75-28.25, and 28.25-28.75, respectively. Column I of Table 6 presents the mean values of the operative temperatures of the ten bins. The vote distribution and the cumulative responses were given as in the central part of the table body.

The distributed votes were then employed to calculate the average vote of each bin. The result could be plotted and illustrated in Fig. 3. It was obvious that linear relationship could be applied well to fit the plot. From the least square regression, the fitted equation could be expressed as:

$$
\mathrm{TSV}=0.677 t_{0}-17.823
$$

By the above equation, the corresponding operative temperature for the thermal neutrality was equal to $26.3^{\circ} \mathrm{C}$ for the Songkhla's subjects.

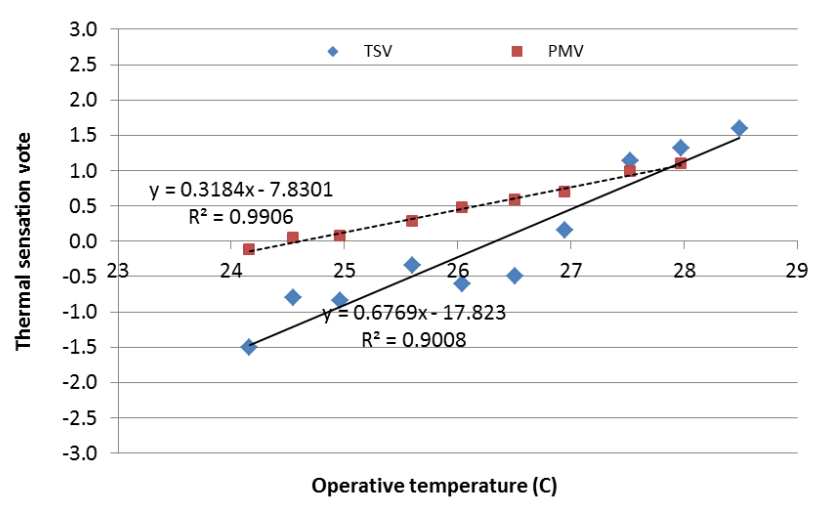

Fig. 3. Relationships of TSV and PMV with $t_{0}$

This time, the sensation votes in each bin were grouped into two sub-categories: the vote "warmer-thanneutral" and the vote "cooler-than-neutral". The votes of the ASHRAE scales $+1,+2$ and +3 were sorted into the first category while those of the scales $-1,-2$ and -3 were sorted into the second category. For the scale 0 (neutrality), the number of votes were split 50:50 to both categories.

Probit analysis was performed with the sorted data to determine the maximum likelihoods of the vote percentages of the two categories. Figure 4 gives the resulting plots of the probit models against the operative temperature.

According to the plot, the vote "cooler-than-neutral" would be $100 \%$ at $t_{0}=21^{\circ} \mathrm{C}$ and would decrease with increasing operative temperature until equal to $0 \%$ at $t_{0}=30^{\circ} \mathrm{C}$. The opposite was true for the vote "warm-thanneutral".

A useful application of probit analysis is to determine the temperature of the thermal neutrality [20]. This could be estimated as temperature corresponding to a 50\% response rate in the probit models. This case, the analysis 
indicated the neutral $t_{o}$ was $26.5^{\circ} \mathrm{C}$. Comparing to the neutral $t_{o}$ values from the TSV model and from the probit model, the values did well agree $\left(26.3^{\circ} \mathrm{C}\right)$.

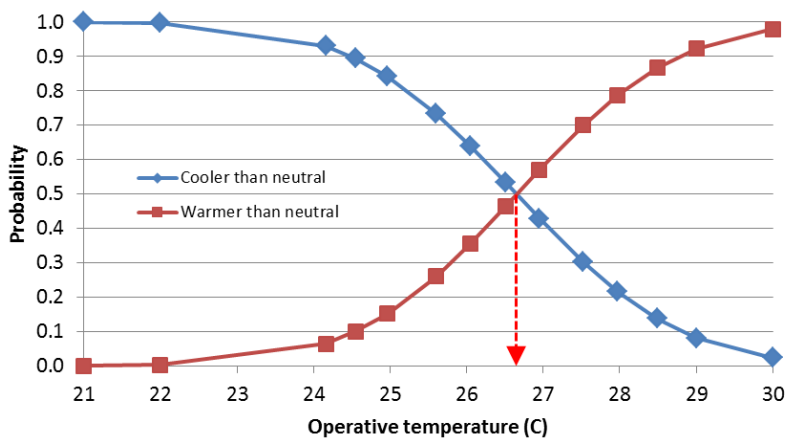

Fig. 4. Probit regression model fitted to thermal sensation percentages.

\subsection{Thermal Acceptability}

The subjects were asked about their acceptability to the prevailing thermal condition at their workstation. The responses of "not accept" were chosen and then sorted into the correspondent $t_{o}$ bins; giving the plot of the percentage of unacceptability in Fig. 5, denoted as "Acceptability question (Obs.)" in the legend. The trend line of the plot from regression was also given in the figure. It was observed that the minimum unacceptability level was at $t_{0}=26.0^{\circ} \mathrm{C}$. Based on $90 \%$ acceptability criteria of ANSI/ASHRAE 55, the operative temperature would be between $24.9^{\circ} \mathrm{C}$ and $26.7^{\circ} \mathrm{C}\left(1.8^{\circ} \mathrm{C}\right.$ range).

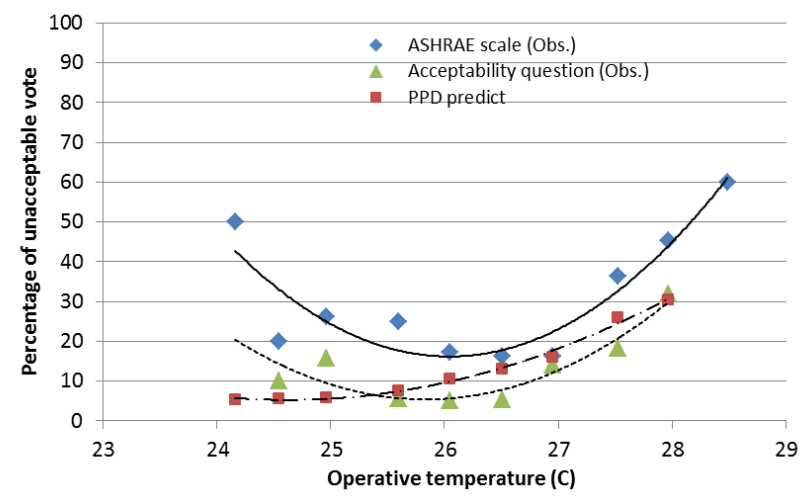

Fig. 5. Observed thermal acceptability related to operative temperature.

It was able to postulate in thermal comfort research that a vote outside the three central ASHRAE sensation scales, i.e. -1 : slightly cool, 0 : neutral, +1 : slightly warm, could express dissatisfaction or unacceptability. The percentages of such votes within each of the $t_{0}$ bins were determined and presented by another trend line denoted as "ASHRAE scale (Obs.)" in the legend. It was obvious that the result from this indirect assessment was rather consistent with the direct assessment, giving $t_{0}$ of the comfort neutrality at $26.1^{\circ} \mathrm{C}$. It also exhibits that about $18 \%$ of the subjects not accept this neutral temperature.
The last trend line denoted as "PPD predict" was superimposed in Fig. 5 to present the relationship of the mean PPD index value with $t_{0}$. It could be observed that this trend line did not well compare to the first two lines. A reason would be that the PMV model did not accurately predict the subjects' thermal sensation.

\subsection{Thermal Preference}

Subjects were also asked whether they would prefer to feel cooler or warmer. The preference votes were arranged for the probit analysis. Figure 6 presents the maximum likelihood of the preference percentages with $t_{0}$.

Considering that the intersection point of the two lines: "want to be cooler" and "want to be warmer" of the probit models represented the optimum thermal neutrality, it could be seen in Fig. 6 that this occurred at operative temperature approximately $26.3^{\circ} \mathrm{C}$. Again, at this preferable temperature, there existed a considerable number of the subjects (20 percent) desired to change their prevailing condition to either warmer or cooler. This preferable temperature was quite consistent with the neutral temperature as shown in Fig. 4 and Fig. 5.

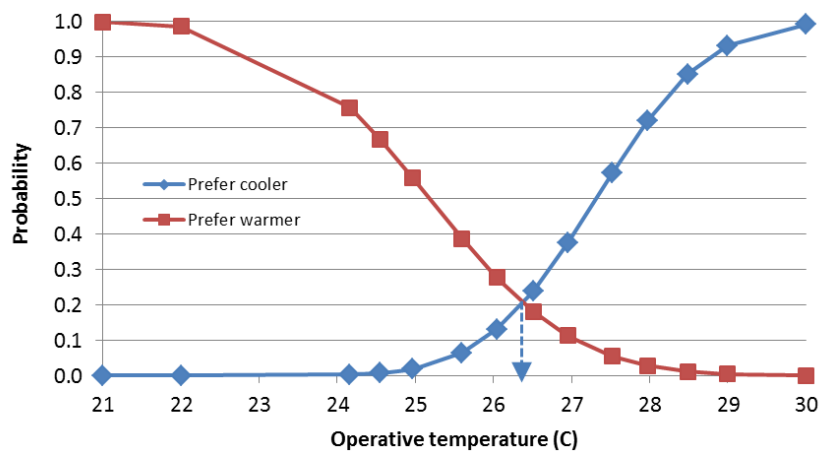

Fig. 6. Probit regression model of thermal preference percentages.

\subsection{Air Movement}

Air movement influences physically and psychologically on the subject's thermal comfort. Questions on its acceptability and preference by subjects were included in the questionnaire. Referring to the scales in Table 1, the mean air movement acceptability and preference ratings as reported in Table 5 implies the subjects accepted the existing air movement, but preferred higher velocity level if possible.

For further analysis, the responses of the air movement preferences have been binned into $0.5^{\circ} \mathrm{C} t_{0}$ intervals and the resulting percentage within each bin had been plotted in Fig. 7 .

It could be observed that higher air movement was preferable with increasing $t_{0}$. At the neutral optimum temperature $\left(26.3^{\circ} \mathrm{C}\right), 40$ percent of the subjects desired for more air movement than they were experiencing. 


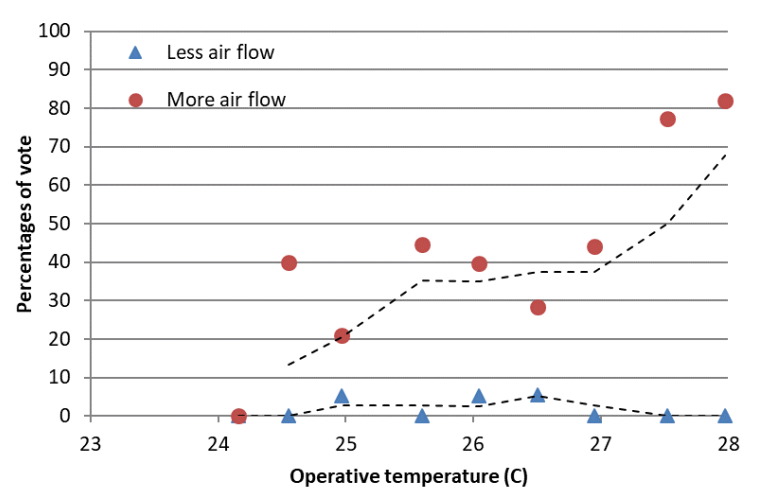

Fig. 7. Air movement preference related to operative temperature.

On this question, few of the subjects chose "prefer lower air velocity". In addition, this proportion decreased with increasing $t_{o}$; coincident with the increasing of the desire for higher air movement.

\subsection{Air Humidity}

Air humidity is a considered environmental factor in this study. As shown in Fig. 1, the relative humidity of ambient air was measured from $37 \%$ up to $98 \%$. However, the condition of the surveyed rooms was controlled; the mean value of the indoor air relative humidity was about $57.2 \%$ with a standard deviation as small as $5.6 \%$. In the table, the indoor air humidity was also expressed in terms of dew-point temperature $\left(t_{d p}\right)$.

In the survey, the humidity acceptability was asked to subjects: "Did you accept the room air humidity?" Referring to the scales in Table 2, the mean value of the humidity acceptability rating of -0.1 (Table 5) expressed the subjects' satisfaction on the humidity level.

The air humidity preference was also questioned to the subjects. Examining the mean value of the humidity preference at 0.16 (Table 5), it indicated no need to be change the prevailing humidity level in their spaces. Figure 8 shows the vote percentage of humidity preference related to dew point temperature. The plot in the figure shows the preference for higher humidity level across the full humidity range.

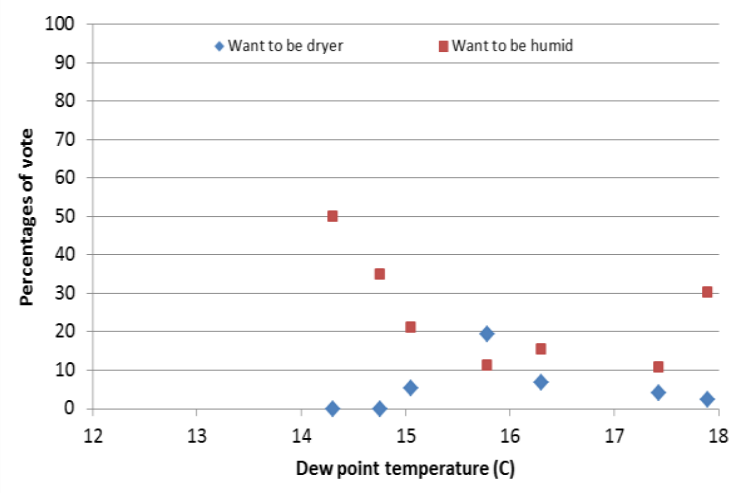

Fig. 8. The vote percentage of humidity preference related to dew point temperature.

\section{Discussions}

In Section 4, the observed indoor environments were presented and evaluated against the design criteria of the indoor air-conditioning in Thailand. The responses of the subjects to such environments were determined using the TSV index. The PMV index was also calculated from the measured indoor data and its regression trend line was superimposed in Fig. 3. The plots show that the average PMV value did not agree well with the corresponding average TSV value. The neutral operative temperature given by the PMV model was at $24.5^{\circ} \mathrm{C}$, almost two degree cooler than that of the TVS $\left(26.3^{\circ} \mathrm{C}\right)$.

The gradient of the PMV trend line indicated the subject's sensation would shift 1 scale unit by changing of the operative temperature $3^{\circ} \mathrm{C}$ departure from the neutrality. According to ANSI/ASHRAE 55, the thermal comfort zone would correspond with \pm 0.5 PMV value. Hence, the zone was curbed by the lower and upper temperatures of $23.0^{\circ} \mathrm{C}$ and $26.0^{\circ} \mathrm{C}$, respectively. Examining Fig. 3 again, the TVS trend line presented its steeper gradient of the thermal sensation with the operative temperature. The lower and upper temperature limits of the comfort zone within \pm 0.5 sensation scale were $25.6^{\circ} \mathrm{C}$ and $27.1^{\circ} \mathrm{C}$, respectively. The limit range was only $1.5^{\circ} \mathrm{C}$, implying that our subjects were more sensitive to the temperature changing.

The comparison above presented that the PMV index could not be applied well to identify the neutral temperature and comfort zone for Songkhla's subjects.

In the thermal acceptability aspect, it is a truism that no thermal condition acceptable by all people with no compliant. The predicted percentage of dissatisfied (PPD) model by Fanger quantified an expected 5\% of thermal dissatisfaction at neutral temperature, and 10\% within \pm 0.5 PMV comfort zone.

In Fig. 5, the observed unacceptability was derived from the direct- and indirect- methods. The trend lines of the percentage of dissatisfied from the direct method showed a good agreement with that prescribed in ANSI/ASHRAE 55 standard. However, the observation from the indirect method exhibited a sizable percentage of dissatisfied of $18 \%$ at neutrality and $23 \%$ at the margins of the comfort zone $\left(25 \cdot 6-27 \cdot 1^{\circ} \mathrm{C}\right)$. Regarding these results, it was likely that the dissatisfaction in the comfort zone was greater than the prescription of Standard 55.

There were several factors that potentially caused higher dissatisfactory. In our survey, the air movement seemed rather low with a mean velocity of $0.1 \mathrm{~m} / \mathrm{s}$. Although it was in compliance with the standard recommendation, the subjects preferred to increase the velocity in the comfort zone as high as $20-40 \%$. Few percent of the subjects requested for lower air velocity. Certainly, the over cooling by draft was not the comfort issue for the surveyed subjects.

The observed relative humidity seemed rather high with a mean value of about $60 \%$; however, its variation 
was still within the acceptable range of the standard. Figure 8 showed a small portion of the subjects in comfort zone requested to increase or decrease the room air humidity.

Vertical temperature stratification is mentioned in ANSI/ASHRAE 55 [2] as a potential source of complaint. The allowable vertical temperature difference from head to toe for seated occupants was prescribed not exceeding $3.0^{\circ} \mathrm{C}$, but in the survey no one complaint on this issue.

Standard 55 suggests that radiant temperature asymmetries in the vertical plane may be a source of complaint, but none of them under investigation exceeded the standards' plane radiant asymmetry limit of $10^{\circ} \mathrm{C}$. From the measurement results, the mean radiant temperature was almost equal in value to the indoor air temperature.

Our survey results were also compared to some past studies carried out in hot humid climate. De Dear conducted two comfort surveys: the one in Townville, tropical north of Australia [8] and the other in Singapore's capital city [7]. At Townville, the neutrality of the European people in air-conditioned rooms corresponded with the operative temperature of 23.5$24.0^{\circ} \mathrm{C}$; matching well with the PMV model. The Singapore's study reported the neutrality of Southeast Asia people at the operative temperature of $23.5^{\circ} \mathrm{C}$, consistent with those in Townville. Due to the finding, the non-quantifiable influencing factor on the thermal sensation was discussed regarding the people expectation on indoor temperature practically set following international/local air-conditioning standard $\left(23-25^{\circ} \mathrm{C}\right)$ and well adopted for benchmarking the thermal sensation. Another factor concerned on the Townville case was the extent to which the majority of the samples exposed to the hot-humid climate found to be relatively small; they frequently used air-conditioner in their bedroom and living room at home.

In Thailand, Busch conducted his thermal comfort survey for air-conditioned buildings in Bangkok in 1992 [5]. He reported the neutral operative temperature was $24.5^{\circ} \mathrm{C}$. Hiranlabh et al. conducted a survey in three provinces: Cheingmai, Bangkok, and Prachuap Khiri Khan. The survey results from Bangkok gave the neutrality condition at the operative temperature $25.0^{\circ} \mathrm{C}$. This temperature was agreed with the Thai's airconditioning standard and just $0.5^{\circ} \mathrm{C}$ above the temperature studied by Busch. Hiranlabh reported that around $60 \%$ of the subjects participated in the survey used the room air-conditioner at home.

For Prachuap Khiri Khan, a province in western part of Thailand (latitude $11.5^{\circ} \mathrm{N}$ and longitude $99.5^{\circ} \mathrm{E}$ ), the survey with 200 subjects that $34 \%$ used room airconditioner at home reported the neutral temperature at $26.0^{\circ} \mathrm{C}$. Our study results seemed quite complement with the Prachuap's study to present the thermal comfort of Thai's people in hot humid climate. The two studies exhibited the influence of acclimatization and the behaviour of air-conditioning use on thermal comfort.

In comparing our Songkhla results with the Townville's case, although the results seem disparity for the neutral temperature, they were quite consistent for which the subjects' behaviours in both locations were hyper-sensitive to the indoor air temperature. As it can be observed in Fig. 3, the PMV regression model underestimated the actual thermal sensation. The people were more sensitive to temperature in air-conditioned buildings departure away from the neutrality even though the people were tolerant with hot and humid condition.

In the comfort viewpoint, our field survey was carried out in which the existed room conditions did not adjust or modified for the thermal sensation evaluation. It thus reflected the acceptable thermal condition of the subject majority. Under a pace of increasing penetration of building air-conditioning, promotion of setting room air temperature in buildings at $26^{\circ} \mathrm{C}\left(1{ }^{\circ} \mathrm{C}\right.$ above the upper limit in Thai's standard) could maintain the satisfactory of thermal comfort of Songkhla people.

Passive building design could be potentially promoted such as insulated roof and solar shading for air-conditioned buildings that helped reducing the room mean radiant temperature, and hence operative temperature. For residential houses, sufficient natural ventilation should be concerned in order that it could reduce the use of air-conditioner at home.

\section{Conclusion}

A field comfort survey of Thai people in airconditioned spaces was conducted in Songkhla. The data from a total of 300 subjects acclimatized in hot humid climate were assessed statistically for their thermal sensation, thermal acceptability and thermal preference. Based on the ASHRAE seven-point comfort scale, the thermal neutrality of the subjects in sedentary activity and with the mean clo value of 0.51 was correspondent to the operative temperature at $26.3^{\circ} \mathrm{C}$. The acceptable range of the operative temperature for $\mathrm{TSV} \pm 0.5$ was $25.6-27.1^{\circ} \mathrm{C}$ $\left(1.5^{\circ} \mathrm{C}\right.$ range). Our results indicated the thermal sensation of the subjects could not be well predicted by the PMV model. The subjects were hyper-sensitive to temperature, but not to the room relative humidity. Although the air movement in the air-conditioned rooms could compiled with the Thai's standard, the subjects were preferable to higher air velocity surrounding their bodys.

\section{Acknowledgement}

The financial support from the National Science and Technology Development Agency (NSTDA), grant no. P-16-51993 through this research project is gratefully acknowledged.

\section{References}

[1] ASHRAE Handbook, Fundamentals, ASHRAE, American Society of Heating, Refrigerating, and Air-Conditioning Engineers, Atlanta, 2005. 
[2] Standard 55-2017, Thermal Environmental Conditions for Human Occupancy, ASHRAE, American Society of Heating, Refrigerating, and Air-conditioning Engineers, Atlanta, GA, 2017.

[3] P. O. Fanger, Thermal Comfort, Analysis and Applications in Environmental Engineering. New York: McGrawHill, 1972.

[4] A. Auliciems, "Towards a psycho-physiological model of thermal comfort perception," Int J Biometeorol, vol. 25, pp. 109-122, 1981.

[5] J. Busch, "Thermal respnses to the Thai office environment," ASHRAE Trans., vol. 96, no. 1, pp. 859-872, 1990.

[6] J. Khedari, N. Yamtraipat, and J. Hirunlabh, "Thermal comfort standards for air conditioned buildings in hot and humid Thailand considering additional factors of acclimatization and education level," Solar Energy, vol. 32, pp. 504-517, 2005.

[7] R. J. De Dear, K. G. Leow, and S. C. Foo, "Thermal comfort in the humid tropics: Field experiments in air-conditioned and naturally ventilated buildings in Singapore," Int J Biometeorol, vol. 34, pp. 259-265, 1991.

[8] A. Auliciems, and R. de Dear, "Air-conditioning in a tropical climate: Impacts upon European residents in Darwin, Australia," Int J Biometeorol, vol. 30, pp. 259-282, 1983.

[9] R. de Dear, "Field experiments on occupant comfort and office thermal environments in a hothumid climate," ASHRAE Trans, vol. 100, no. 2, pp. 457-475, 1994.

[10] C. Candido, R.J. de Dear, R. Lamberts, and L. Bittencourt, "Air movement acceptability limits and thermal comfort in Brazil's hot humid climate zone," Build. Environ., vol. 45, pp. 222-229, 2010.

[11] L. A. López-Pérez, J.J. Flores-Prieto*, and C. RíosRojas, "Adaptive thermal comfort model for educational buildings in a hot-humid climate," Build. Environ., vol. 150, pp. 181-194, 2019.
[12] C. Buonocore, R. D. Vecchi, V. Scalco, and R. Lamberts, "Thermal preference and comfort assessment in air-conditioned and naturallyventilated university classrooms under hot and humid conditions in Brazil," Energy Build., vol. 211, pp. 1-13, 2020.

[13] Y. He, N. Li, W. Zhang, and J. Peng, "Overall and local thermal sensation \& comfort in airconditioned dormitory with hot-humid climate," Build. Environ., vol. 101, pp. 102-109, 2016.

[14] M. Indraganti, R. Ooka, H. B. Rijal, and G.S. Brager, "Adaptive model of thermal comfort for offices in hot and humid climates of India," Build. Environ., vol. 74, pp. 39-53, 2014.

[15] N. Makaremi, E. Salleh, M. Z. Jaafar, and A. Ghaffarian Hoseini, "Thermal comfort conditions of shaded outdoor spaces in hot and humid climate of Malaysia," Build. Environ., vol. 48, pp. 7-14, 2012.

[16] H. Djamila, C.M. Chu, and S. Kumaresan, "Field study of thermal comfort in residential buildings in the equatorial hot-humid climate of Malaysia," Build. Environ., vol. 62, pp. 133-142, 2013.

[17] S. Mirrahimi, M. F. Mohamed, L. C. Haw, N. L. N. Ibrahim, W. F. M. Yusoff, and A. Aflaki, "The effect of building envelope on the thermal comfort and energy saving for high-rise buildings in hothumid climate," Renew. Sustain. Energy Rev., vol. 53, pp. 1508-1519, 2016.

[18] Standard for Air-Conditioning and Ventilation Systems, EIT Standard 3003-50, The Engineering Institute of Thailand.

[19] Ergonomics of the Thermal Environment - Instrument for Measuring Physical Quantities, ISO 7726, ISO, International Organization for Standardization, Geneva, Switzerland, November, 1998.

[20] E. R. Ballantyne, R. K. Hill, and J. W. Spencer, "Probit analysis of thermal sensation assessments," Int J Biometeorol, vol. 21, no. 1, pp. 29-43, 1977.

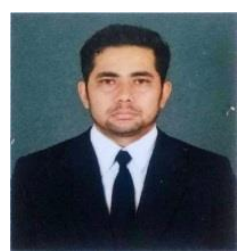

Ashmin Aryal has received his B.Eng. (Mechanical Engineering) from Kathmandu University; M.Eng. (Technology) from Guru Jambheshwor University of Science and Technology, India. Currently he is pursuing a Doctoral degree in Energy Technology at Joint Graduate School of Energy and Environment, King Mongkut's University of Technology Thonburi.

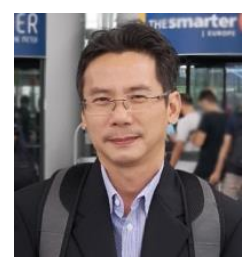

Pipat Chaiwiwatworakul has received his B.Eng. (Mechanical Engineering) from Chulalongkorn University; M.Eng. and D.Eng (Energy Technology) from the Asian Institute of Technology. He is now a lecturer at Energy Division, Joint Graduate School of Energy and Environment, King Mongkut's University of Technology Thonburi. 

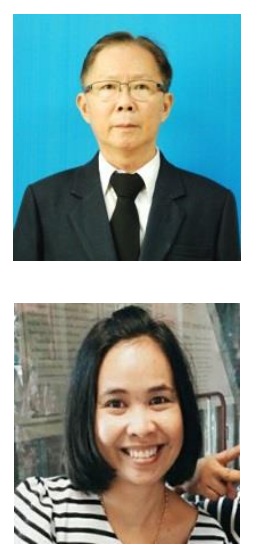

Surapong Chirarattananon has received his B.E (Electrical Engineering), the University of New South Wales, Australia; M.Eng.Sc. (Electrical Engineering), Monash University, Australia; Ph.D. Electrical Engineering, the University of Newcastle, Australia. He is now a professor at Energy Division, Joint Graduate School of Energy and Environment, King Mongkut's University of Technology Thonburi.

Satinee Wattanakit received the Bachelor of Fine Arts Program in Interior Design, Kasem Bundit University, and Master of Architecture Program in Interior Architecture, King Mongkut's Institute of Technology Ladkrabang. She is now a lecturer at Faculty of Architecture, Rajamangala University of Technology Srivijaya. 